\title{
7ISES

\section{Intrusive Rock Database for the Digital Geologic Map of Utah}

C.J. Nutt ${ }^{1}$ and Steve Ludington ${ }^{2}$

Open-File Report 03-486

Version 1.0

2003

U.S. Department of the Interior

Gail A. Norton, Secretary

U.S. Geological Survey

Charles G. Groat, Director

Any use of trade, firm, or product names is for descriptive purposes only and does not imply endorsement by the U.S. Government.

${ }^{1}$ U.S. Geological Survey, Denver, CO 80225

${ }^{3}$ U.S. Geological Survey, Menlo Park, CA 94025 


\section{Introduction and Background}

Digital geologic maps offer the promise of rapid and powerful answers to geologic questions using Geographic Information System software (GIS). Using modern GIS and database methods, a specialized derivative map can be easily prepared. An important limitation can be shortcomings in the information provided in the database associated with the digital map, a database which is often based on the legend of the original map. The purpose of this report is to show how the compilation of additional information can, when prepared as a database that can be used with the digital map, be used to create some types of derivative maps that are not possible with the original digital map and database.

This Open-file Report consists of computer files with information about intrusive rocks in Utah that can be linked to the Digital Geologic Map of Utah (Hintze et al., 2000), an explanation of how to link the databases and map, and a list of references for the databases. The digital map, which represents the 1:500,000-scale Geologic Map of Utah (Hintze, 1980), can be obtained from the Utah Geological Survey (Map 179DM). Each polygon in the map has a unique identification number. We selected the polygons identified on the geologic map as intrusive rock, and constructed a database (UT_PLUT.xls) that classifies the polygons into plutonic map units (see tables). These plutonic map units are the key information that is used to relate the compiled information to the polygons on the map.

The map includes a few polygons that were coded as intrusive on the state map but are largely volcanic rock; in these cases we note the volcanic rock names (rhyolite and latite) as used in the original sources Some polygons identified on the digital state map as intrusive rock were misidentified; these polygons are noted in a separate table of the database, along with some information about their true character.

Fields may be empty because of lack of information from references used or difficulty in finding information. The information in the database is from a variety of sources, including geologic maps at scales ranging from 1:500,000 to $1: 24,000$, and thesis monographs. The references are shown twice: alphabetically and by region.

The digital geologic map of Utah (Hintze and others, 2000) classifies intrusive rocks into only 3 categories, distinguished by age. They are: Ti, Tertiary intrusive rock; Ji, Upper to Middle 
Jurassic granite to quartz monzonite; and pCi, Early Proterozoic to Late Archean intrusive rock. Use of the tables provided in this report will permit selection and classification of those rocks by lithology and age.

This database is a pilot study by the Survey and Analysis Project of the U.S. Geological Survey to characterize igneous rocks and link them to a digital map. The database, and others like it, will evolve as the project continues and other states are completed. We release this version now as an example, as a reference, and for those interested in Utah plutonic rocks. 
CLICK ON THE LINKS BELOW TO VIEW THIS REPORT

Data characteristics

$\underline{\text { Data }}$

How to use the database

$\underline{\text { The plut_name field }}$

$\underline{\text { Data compilation }}$

$\underline{\text { References cited }}$

References used to compile the database

References by location 


\section{Data characteristics}

The The workbook, UTAH_PLUT.XLS, contains 9 worksheets, TITLE, CORRELATE, LITHOLOGY, AGE_SUM, RAD_AGE, DEPOSITS, ERRORS, DOCUMENTATION, and CLASSIFICATION. The first is the title page, and the last three provide supplementary information. Each of the rest is a table of attributes that applies to plutonic rock map polygons; these are also provided as tabdelimited .txt files suitable for use directly in GIS applications.

The CORRELATE table is the master table that relates quasi-stratigraphic units (plut_name) to the specific individual polygons of the digital geologic map of Utah. The plut_name was chosen to refer to a nearby geographic feature, or other commonly used name, tempered by the goal that each plut_name would represent a coherent group of lithologies, textures, and other attributes. In a very few cases where no appropriate name was apparent, a serial number was appended to the name of the 1:250,000 scale topographic quadrangle.

The LITHOLOGY table is the largest, with the largest number of fields. It contains information about lithology, mineralogy, texture, structure, geochemistry, hydrothermal alteration, and data quality, all related to the units (plut_name) in the CORRELATE table. There are as many records for each plut_name as are necessary to adequately describe the unit. Any unique combination of lith_class and lith_form requires an additional record. The maximum in the table is 8 records, which were required to describe Mineral_Mts_02. The numbers compiled in the percent field are percentages for each unique lithology; they add to 100 percent for each plut_name. We make no claim these figures are accurate to the two significant figures we use; they are estimates only.

The AGE_SUM table combines information about stratigraphic ages reflected by geologic setting of each plut_name, along with a best numerical estimate for the age of each unit. The quality of this estimate varies widely, but it permits the plotting and selection of the units mathematically and logically.

The RAD_AGE table compiles information about radiometric ages that were encountered during the research to complete the other tables. We make no claim that it is comprehensive. It serves as a reference for many of the age estimates in the AGE_SUMMARY table.

The DEPOSITS table contains information about associated mineral deposits, including mining 
districts, commodities, and mineral deposit types.

The DOCUMENTATION worksheet contains a description of the fields in the other worksheets, in the form of instructions for compilers.

The ERRORS worksheet lists 24 polygons that are coded as intrusive in the digital map database that, when examined on larger scale maps, prove not to be intrusive rocks. We did not try to determine if these were errors in the original map (Hintze, 1980) or introduced during production of the digital map (Hintze and others, 2000).

The DOCUMENTATION worksheet contains guidelines for the format of the individual fields in the data tables, and can serve as a guide to future compilers, as well.

The CLASSIFICATION worksheet portrays the hierarchical classification of plutonic rock names used in the lith_class field of LITHOLOGY. This hierarchy is very close to the recommendations of Streckeisen (1976). 
Data

\section{Download database files}

UT_PLUT.xls (Microsoft Excel, 876 KB)

correlate.txt (tab-separated value, 16 KB)

lithology.txt (tab-separated value, 96 KB)

age_sum.txt (tab-separated value, 16 KB)

rad_age.txt (tab-separated value, 36 KB) 


\section{How to use the database}

By linking the tables in this database to the Digital Map of Utah (Hintze et al., 2000), those polygons that are plutonic will acquire additional attributes that can be used to construct complex topical maps. This database must be joined to an existing copy of the Digital Map of Utah (Hintze and others, 2000). We made tests with ArcMap 8.2, and describe how to use it with that system, although similar methods will apply to other GIS software.

The first step is to add the tables CORRELATE.txt, LITHOLOGY.txt, AGE_SUM.txt, RAD_AGE.txt, and DEPOSITS.txt to your ArcMap document. Then join the CORRELATE.txt table to the attribute table of the Utah map, using the field UTGEOMAP_ in the UTGEOMAP attribute table, and spatobj_id in the CORRELATE table as keys. Once this is successful, the other tables LITHOLOGY.txt, AGE_SUM.txt, and RAD_AGE.txt, and can be related (linked) to the UTGEOMAP attribute table, using plut_name as the relate field. Relates in ArcMap 8.x are termed links in ArcView 3.x. Figure 1 shows the structure of the resulting database.

To join two tables means to append the attributes in one table to those in the first, using a field common to both tables. This, of course, is only possible when there is a one-to-one relationship between the records in the two tables to be joined. This requirement is met by the CORRELATE table, which has one (and only one) entry for each polygon in the spatial database that refers to intrusive rock. However, note that a few polygons that are coded $\mathrm{Ti}$ in the spatial database do not have corresponding records in CORRELATE, because they were found to be errors, i.e. they do not refer to polygons that actually represent intrusive rock.

To relate, or link, two tables means, in this case, to define the relationship between some attributes about intrusive rocks in a table and the related records in the spatial database being used. This relationship can be defined even when the relationship between the two tables is not one-to-one. Using the data in this report, the single polygon represented by the plut_name Abajo_Mtns_East_01 consists of both diorite and monzodiorite, and part of the polygon represents a laccolith, part a stock. Thus, there are 4 entities in the LITHOLOGY table that relate to Abajo_Mtns_East_01. Selecting for either diorite, monzodiorite, sill, or laccolith will identify the Abajo_Mtns_East_01 polygon.

Because many of the polygons in the Utah digital geologic map contain multiple lithologies, it 


\begin{tabular}{|l|l}
\hline UTGEOMAP & \\
\cline { 1 - 1 } FID & \\
Shape & \\
AREA & \\
PERIMETER & \\
UTGEOMAP & \\
UTGEOMAP_I & JOIN \\
UORMATION & \\
&
\end{tabular}

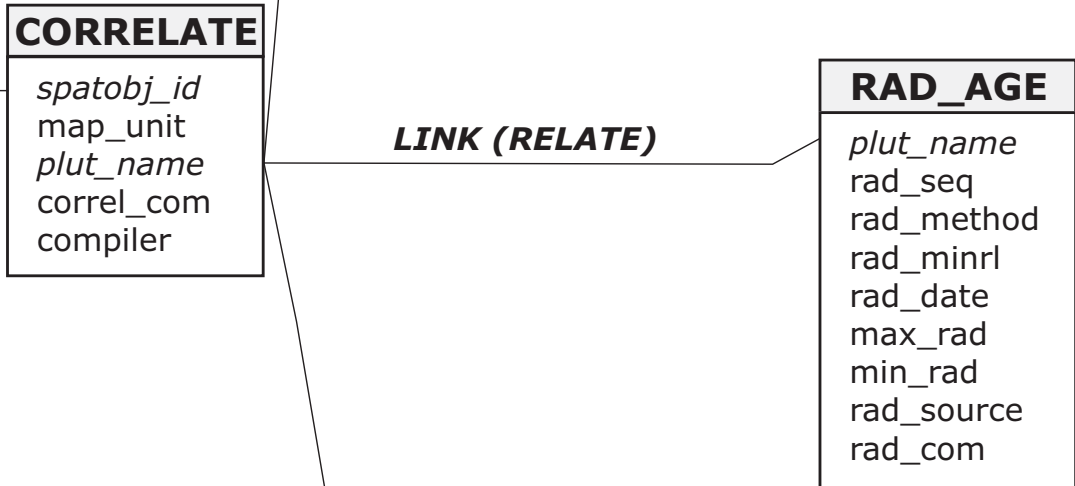

Figure 1. - Diagram showing structure of UT_PLUT database. 
is conceptually impossible to make a map symbolized by rock type. It is, however, possible to make a map showing all polygons that contain some granite. This would be done by selecting all the polygons that contain granite, and making a new spatial file with them. But because many of them also contain granodiorite, it is not possible to directly construct a symbolization scheme based on lithology. 


\section{The plut_name field}

During development of this database, some questions have arisen over the use and nature of the plut_name field. The names used in this field are for the convenience of the compiler, and should be chosen to both minimize extraneous detail, and to maximize information availability.

The complexity of this database is due to both the complexity of nature, and to the varied ways geologic map units are defined and illustrated. In nature, a pluton may consist of several lithologies, either separated by specific boundaries (contacts) or in a continuous, gradational relationship. It may also consist of only one lithology. Conversely, the body, that consists of one or more lithologies, may be exposed at the earth's surface in one continuous outcrop, or in a number of outcrops separated by surficial materials. Likewise, such a body may be portrayed on a geologic map as a single polygon, or as a number of polygons. On a small-scale map like the Utah map, an individual polygon is more likely to represent a number of different lithologies (or ages) than on a large-scale map like a 1:24,000-scale quadrangle. Nevertheless, many of the plutons portrayed on the Utah map consist of several polygons and are relatively homogenuous.

The polygon or polygons that are designated with a single plut_name should generally be as simple as possible, petrologically and temporally. Whenever possible, we assign a geographic name, in some cases, one that has been used informally in the literature. When an appropriate name is not apparent, we used the name of the 1 degree $\times 2$ degree quadrangle, concatenated with a serial number (as in SALINA_01); names of this nature are in all caps. If, during compilation, a group of polygons is found to contain radically dissimilar rocks, or rocks of distinctly different ages, every attempt should be made to use multiple plut_names. We have done this in the cases in the CORRELATE table where the serial number part of the plut_name is greater than one. In theory, one could even apply multiple plut_names to a single polygon, but we have not done this. 


\section{Data compilation}

Maps were prepared that portrayed all the polygons coded as intrusive rock (map units Ti, Ji, and $\mathrm{PC}$ ) on the digital representation of the Utah state geologic map (Hintze and others, 2000). Then, in order to assign plut_names and to fill out the tables in UT_PLUT, geologic maps at 1:250,000 to $1: 24,000$ scales were consulted, as well as selected scientific articles that described the rocks in question. The starting point was available 1:250,000 and 1:100,000 scale maps and the GEOREF database. Using references from these maps and database, more detailed information was obtained about the attribute fields in LITHOLOGY and RAD_AGE. In some cases, the 1:250,000 and 1:100,000 maps were the only source of information. The reference list, which is shown both alphabetically and by region, is included to identify the sources of data.

The naming of igneous rocks is always contentious. In these tables, we have used the field rock_name for the name as used in reference publications. Entries in the lith_class field are limited to the hierarchy of names listed in the last worksheet of the spreadsheet, CLASSIFICATION. This hierarchy is closely similar to the one published by Streckeisen (1976). 


\section{References cited}

Hintze, L.F., 1980, Geologic Map of Utah: Utah Geological and Mineral Survey, scale $1: 500,000$.

Hintze, L.F., Willis, G.C., Laes, D. Y. M., Sprinkel, D.A., and Brown, K.D., 2000, Digital Geologic Map of Utah: Utah Geological Survey Map 179DM, scale 1:500,000.

Streckeisen, A.L., 1976, To each plutonic rock its proper name: Earth Science Reviews, v. 12, p. 1-33. 


\section{References used to compile the database}

Abott, J.T., Best, M.G., and Morris, H.T., 1983, Geologic map of the Pine Grove-Blawn Mountain area, Beaver County, Utah: U.S. Geological Survey Miscellaneous Investigations Series Map I-1479, scale 1:24,000.

Abou-Zied, S., 1973, Geology of the Milford Flat quadrangle, Star district, Beaver County, Utah, in Hintze L.F. and Whelan, J.A., eds., Geology of the Milford area: Utah Geological Association Publication 3, p. 43-48.

Aleinikoff, J.N., Nielson, D.L., Hedge, C.E., and Evans, S.H., Jr., 1986, Geochronology of Precambrian and Tertiary rocks in the Mineral Mountains, south-central Utah: U.S. Geological Survey Bulletin 1622, p. 1-12.

Allmendinger, R.W., and Jordan, T.E., 1989, Geologic map of the Newfoundland Mountains, northwestern Utah: U.S. Geological Survey Map MF-2087, scale 1:31,680.

Armstrong, R.L., 1970, Geochronology of Tertiary igneous rocks, eastern Basin and Range province, western Utah, eastern Nevada, and vicinity, U.S.A. : Geochimica et Cosmochimica Acta, v. 34, p. 203-232.

Babcock, R.C., Jr., Ballantyne, and G.H., Phillips, C.H., 1997, Summary of the geology of the Bingham district, Utah: Society of Economic Geologists Guidebook 29, p. 113-132.

Baetcke, G.B., 1969, Stratigraphy of the Star Range and reconnaissance study of three selected mines: PhD dissertation, University of Utah, $184 \mathrm{p}$.

Baker, A.A., Calkins, F.C., Crittenden, M.D., Jr., and Bromfield, C.S., 1966, Geologic map of the Brighton quadrangle, Utah: U.S. Geological Survey Geologic Quadrangle Map GQ-534, scale 1:24,000.

Barker, D.S., 1995, Crystallization and alteration of quartz monzonite, Iron Springs mining district, Utah: relation to associated iron deposits: Economic Geology, v. 90, p. 2,1972,217 . 
Barosh, P.J., 1960, Beaver Lake Mountains, Beaver County, Utah-their geology and ore deposits: Utah Geological and Mineralogical Survey Bulletin 68, 89 p.

Best, M.G., Armstrong, R.I., Graustein, W.C., Embree, G.F., and Ahlborn, R.C., 1974, Mica granites of the Kern Mountains plutons, eastern White Pine Country, Nevada: remobilized basement of the Cordilleran migeosyncline: Geological Society of America Bulletin, v. 85, p. 1,277-1,286.

Best, M.G., and Grant, S. K., 1987, Stratigraphy of the volcanic Oligocene Needles Range Group in southwestern Utah and eastern Nevada: U.S. Geological Survey Professional Paper 1433-A, 28 p.

Best, M.G., Henage, L.F., and Adams, J.A.S., 1968, Mica peridotite, wyomingite, and associated potassic igneous rocks in northeastern Utah: American Mineralogist, v. 53, p. 1,041-1,048.

Best, M.G., Lemmon, D.M., and Morris, H.T., 1989, Geologic map of the Milford quadrangle and east half of the Frisco quadrangle, Beaver County, Utah: U.S. Geological Survey Miscellaneous Investigations Series Map I-1904, scale 1:50,000.

Best, M.G., Mehnert, H.H., Keith, J.D., and Naeser, C.W., 1987, Miocene magmatism and tectonism in and near the southern Wah Wah Mountains, southwestern Utah: U.S. Geological Survey Professional Paper 1433-B, 31-47.

Billingsley, G.H., Huntoon, D.W., and Breed, W.J., 1987, Geologic map of the Capital Reef National Park and vicinity, Utah: State of Utah, Department of Natural Resources, Utah Geologic and Mineral Survey Map 87, scale 1:62,500.

Borrok, D., Kesler, S. E., Vogel, T. A., 1999, Sulfide mineral in intrusive and volcanic rocks of the Bingham-Park City Belt, Utah: Economic Geology, v. 94, p. 1,213-1,230.

Bryant, B., 1990, Geologic map of the Salt Lake City 30'x 60' quadrangle, north-central Utah, and Unita County, Wyoming: U.S. Miscellaneous Investigations Series Map I-1944, scale $1: 100,000$.

Butler, B.S., 1913, Geology and ore deposits of the San Francisco and adjacent districts, Utah: U.S. Geological Survey Professional Paper 80, 212 p. 
Christiansen, E.H., 1995, Granites, subduction, and extension in the basin and range province, western USA: U.S. Geological Survey Circular 1129, p. 35-36.

Christiansen, E.H., Stuckless, J.S., Funkhouser-Marolf, M.J., and Howell, K.H., 1985, Canadian Institute of Mining and Metallurgy Special Volume 39, p. 303-321.

Compton, R.R., 1972, Geologic map of the Yost quadrangle, Box Elder County, Utah, and Cassia County, Idaho: U.S. Geological Survey Miscellaneous Investigations Series Map I-672, 7 p., scale 1:31,680.

Compton, R.R., 1972, Geologic map of the Park Valley quadrangle, Box Elder County, Utah, and Cassia County, Idaho: U.S. Geological Survey Miscellaneous Investigations Series Map 1-873, 6 p., scale 1:31,680.

Compton, R.R., Todd, V.R., Zartman, R.E., and Naeser, C.W., 1977, Oligocene and Miocene metamorphism, folding, and low-angle faulting in northwestern Utah: Geological Society of America Bulletin, v. 88, p. 1,237-1,250.

Crittenden, M.D., Jr., 1965, Geology of the Draper quadrangle, Utah: U.S. Geological Survey Geologic Quadrangle Map GQ-377, scale 1:24,000.

Crittenden, M.D., Jr., 1965, Geology of the Dromedary Peak quadrangle, Utah: U.S. Geological Survey Geologic Quadrangle Map GQ-378, scale 1:24,000.

Crittenden, M.D., Jr., 1965, Geology of the Mount Aire quadrangle, Salt Lake County, Utah: U.S. Geological Survey Geologic Quadrangle Map GQ-379, scale 1:24,000.

Crittenden, M.D., Jr., 1965, Geology of the Sugar House quadrangle, Salt Lake County, Utah: U.S. Geological Survey Geologic Quadrangle Map GQ-380, scale 1:24,000.

Crittenden, M.D., Jr., Calkins, F.C., and Sharp, B.J., 1966, Geologic map of the Park City West quadrangle, Utah: U.S. Geological Survey Geologic Quadrangle Map GQ-535, scale $1: 24,000$.

Crittenden, M.S., Jr., Stuckless, J.S., Kistler, R.W., and Stern, T.W., 1973, Radiometric dating of intrusive rocks in the Cottonwood area: U.S. Geological Survey Journal of Research, v. 1, p. 173-178. 
Cunningham, C.G., Rasmussen, J.D., Steven, T.A., Rye, R.O., Rowley, P.D., Romberger, S.B., and Selverstone, J., 1998, Hydrothermal uranium deposits containing molybdenum and fluorite in the Marysvale volcanic field, west-central Utah: Mineralium Deposita 33, p. 477-494.

Cunningham, C.G., Steven, T.A., Rowley, P.D., Glassgold, L.B., and Anderson, J.J., 1993, Geologic map of the Tushar Mountains and adjoining areas, Marysvale volcanic field, Utah: U.S. Geological Survey Miscellaneous Investigations Series Map I-1430-A.

Cunningham, C.G., Steven, T.A., Rowley, P.D., Naeser, C.W., Mehnert, H.H., Hedge, C.E., and Ludwig, K.R., 1994, Evolution of volcanic rocks and associated ore deposits in the Marysvale volcanic field, Utah: Economic Geology, v. 89, p. 2,003-2,005.

Deino, A., and Keith, J.D., 1997, Ages of volcanic and intrusive rocks in the Bingham mining district, Utah: Society of Economic Geologists Guidebook 29, p. 91-100.

Delaney, P.T., and Gratner, A.E., 1997, Physical processes of shallow mafic dike emplacement near the San Rafael Swell, Utah: Geological Society of America Bulletin v. 109 , no. 9 , p. $1,177-1,192$.

Doelling, H.H., 1980, Geology and mineral resources of Box Elder County, Utah: Utah Geological and Mineral Survey Bulletin 115, 251 p.

Eppinger, R.G., Winkler, G.R., Cookro, T.M., Shubat, M.A., Blank, H.R., Crowley, J.K., Kucks, R.P., and Jones, J.L., 1990, Preliminary assessment of the mineral resources of the Cedar City $1^{\circ}$ × $2^{\circ}$ quadrangle, Utah: U.S. Geological Survey Open-File Report 90-34, $146 \mathrm{p}$.

Fleck, R.J., Anderson, J.J., and Rowley, P.D., 1975, Chronology of mid-Tertiary volcanism in High Plateaus region of Utah: Geological Society of America Special Paper 160, p. 53-61.

Fowkes, E.J., 1964, Pegmatites of Granite Peak Mountain, Tooele County, Utah: Brigham Young University Research Studies, Geology Series, v.11, p. 97-127. 
Gartner, A.E., and Delaney, P.T., 1988, Geologic map showing a late Cenozoic basaltic intrusive complex, Emery, Sevier, and Wayne Counties, Utah: U.S. Geological Survey Map MF-2052, scale 1:48,000.

George, S.E., 1985, Geology of the Fillmore and Kanosh quadrangles, Millard County, Utah: Brigham Young University Geology Studies v. 32, part 1, p. 39-62.

Hacker, D.B., 1998, Catastrophic gravity sliding and volcanism associated with the growth of laccoliths: examples from early Miocene hypabyssal intrusions of the Iron Axis magmatic province, Pine Valley Mountains, southwest Utah: Kent State University, Kent, Ohio, PhD dissertation, 493 p.

Hannah, J.L., and Macbeth, A., 1990, Magmatic history of the East Tintic Mountains, Utah: U.S. Geological Survey Open-File Report 90-95, 24 p.

Hildreth, S.C., Jr., and Hannah, J.L., 1996, Fluid inclusion and sulfur isotope studies of the Tintic mining district, Utah: implications for targeting fluid sources: Economic Geology v. 91 , p. 1,270-1,281.

Hintze, L.F., 1974, Preliminary geologic map of the Wah Wah Summit quadrangle, Millard and Beaver Counties, Utah: U.S. Geological Survey Map MF-637, scale 1:48,000.

Hintze, L.F., 1986, Stratigraphy and structure of the Beaver Dam Mountains, Southwestern Utah: Utah Geological Association Publication 15, p. 1-36.

Hintze, L.F., Lemmon, D.M., and Morris, H.T., 1984, Geologic map of the Frisco Peak quadrangle, Millard and Beaver Counties, Utah: U.S. Geological Survey Miscellaneous Investigations Series Map I-1573, scale 1:48,000.

Hunt, C.B., 1953, Geology and geography of the Henry Mountains region, Utah: U.S. Geological Survey Professional Paper 228, 234 p.

Hunt, G.L., 1988, Petrology of the Mt. Pennell central stock, Henry Mountains, Utah: Bingham Young University Geology Studies, v. 35, p. 81-100. 
Jackson, M., 1998, Processes of laccolithic emplacement in the southern Henry Mountains, southeastern Utah, in Friedman, J.D., and Huffman, A.C., Jr.,eds., Laccolith complexes of southeastern Utah: time of emplacement and tectonic setting-workshop proceedings: U.S. Geological Survey Bulletin 2158, 51-59.

John, D.A., 1989, Geologic setting, depths of emplacement, and regional distribution of fluid inclusions in intrusions of the central Wasatch Mountains, Utah: Economic Geology v. 84, p. 386-409.

John, D.A., 1997, Geologic setting and characteristics of mineral deposits in the central Wasatch Mountains, Utah: Society of Economic Geologists Guidebook 29, p. 11-33.

John, D.A., Turrin, B.D., and Miller, R.J., 1997, New K-Ar and ${ }^{40} \mathrm{Ar} /{ }^{39} \mathrm{Ar}$ ages of plutonism, hydrothermal alteration, and mineralization in the central Wasatch Mountains, Utah: Society of Economic Geologists Guidebook 29, p. 47-57.

Keith, J.D., Dallmeyer, R.D., Kim, C.S., and Kowallis, B.J., 1991, The volcanic history and magmatic sulfide mineralogy of latites of the central East Tintic Mountains, Utah, in Raines, G.L., Lisle, R.E., Schafer, R.W., and Wilkinson, W.H., eds., Geology and Ore Deposits of the Great Basin: Geological Society of Nevada Symposium Proceedings, Reno/Sparks, Nevada, April 1991, p. 461-483.

Keith, J.D., Shanks, W.C., III, Archibald, D.A., and Farrar, E., 1986, Volcanic and intrusive history of the Pine Grove porphyry Molybdenum system, southwestern Utah: Economic Geology v. 81, p. 553-577.

Keith, J.D., Whitney, J.A., Hattori, K., Ballantyne, G.H., Christiansen, E.H., Barr, D.L., Cannan, T.M., and Hook, C.H., 1997, The role of magmatic sulfides and mafic alkaline magmas in the Bingham and Tintic mining districts, Utah: Journal of Petrology, v. 38, no. 12 , p. $1,679-1,690$.

Kim, Choon-Sik, 1997, Petrology of productive intrusions and comagmatic volcanic rocks in the Tintic and East Tintic mining districts, Utah, U.S.A. (1): petrography, mineralogy, and intensive variables: Geoscience Journal, v. 1, no. 3, p. 123-135. 
Laes, D.Y.M., Krahulec, K.S., and Ballantyne, G.H., 1997, Geologic map of the Oquirrh Mountains, Utah: Society of Economic Geologists Guidebook 29, Plate 1, scale $1: 62,500$.

Lee, D.E., Stacey, J.S., and Fischer, L.B., 1986, Muscovite-phenocrystic two-mica granites of northeastern Nevada are late Cretaceous in age: U.S. Geological Survey Bulletin 1622, p. 31-39.

Lemmon, D.M., and Morris, H.T., 1984, Geologic map of the Beaver Lake Mountains quadrangle, Millard and Beaver Counties, Utah: U.S. Geological Survey Miscellaneous Investigations Series Map I-1572, scale 1:48,000.

Lemmon, D.M., Silberman, M.L., and Kistler, R.W., 1973, Some K-Ar ages of extrusive and intrusive rocks of the San Francisco and Wah Wah mountains, Utah, in Hintze L.F. and Whelan, J.A., eds., Geology of the Milford area: Utah Geological Association Publication 3, p. 23-26.

Lindgren, W., 1905, The Annie Laurie mine, Piute County, Utah: U.S. Geological Bulletin 285, p. 87-90.

Lindsey, D.A., Naeser, C.W., and Shawe, D.R., 1975, Ages of volcanism, intrusion and mineralization in the Thomas Range, Keg Mountain and Desert Mountain, western Utah: U.S. Geological Survey Journal of Research, v. 3, no. 5, p. 597-604.

Machette, M.N., and Steven, T.A., 1983, Geologic map of the northwest-quarter of the Beaver Quadrangle, Beaver County, Utah: U.S. Geological Survey Miscellaneous Investigations Series Map I-1445, scale 1:24,000.

Machette, M.N., 1983, Geologic map of the southwest-quarter of the Beaver quadrangle, Beaver County, Utah: U.S. Geological Survey Miscellaneous Investigations Series Map I-1444, scale 1:24,000.

McKee, E.H., Blank, H.R., and Rowley, P.D., 1997, Potassium-argon ages of Tertiary igneous rocks in the eastern Bull Valley Mountains and the Pine Valley Mountains, southwestern Utah: U.S. Geological Survey Bulletin 2153-L, p. 243-252. 
Miller, D.M., 1985, Geologic map of the Lucin quadrangle, Box Elder County, Utah: Utah Geological Survey Map 78, 10 p, scale 1:24,000.

Miller, D.M., 1993, Geologic map of the Crater Island NW quadrangle, Box Elder County, Utah: Utah Geological Survey Map 145, 13 p, scale 1:24,000.

Miller, D.M., Jordan, T.E., and Allmendinger, R.W., 1990, Geologic map of the Crater Island quadrangle, Box Elder County, Utah: Utah Geological and Mineral Survey Map 128, 16 p, scale $1: 24,000$.

Miller, D.M. and Hoisch, T.D., 1995, Jurassic tectonics of northeastern Nevada and Northwestern Utah from the perspective of barometric studies: Geological Society of America Special Paper 299, p. 267-294.

Miller, D.M., Nakata, J.K., and Glick, L.L., 1990, K-Ar ages of Jurassic to Tertiary plutonic and metamorphic rocks, northwestern Utah and northeastern Nevada: U.S. Geological Survey Bulletin 1906, 18 p.

Miller, D.M., and Schneyer, J.D., 1985, Tecoma Quadrangle, Box Elder County, Utah and Elko County, Nevada: Utah Geological Survey Map 77, 8 p, scale 1:24,000.

Miller, E.L., Gans, P.B., Wright, J.E., and Sutter, J.F., 1988, Metamorphic history of the eastcentral basin and range province: tectonic setting and relationship to magmatism, in Ernst, W.G., ed., Metamorphism and crustal evolution of the western United States: Rubey Volume 7, p. 249-282.

Moore, W J., and Sorensen and, M L., 1978, Metamorphic rocks of the Granite Peak area, Tooele County, Utah [abstract]: Geological Society of America Program with Abstracts, v.10, no.5, p. 234.

Moore, W J., and Sorensen and, M L., 1978, Reconnaissance geologic map of northern Simpson Mountains, Davis Mountain, and adjacent area, Tooele County, Utah: U.S. Geological Survey Miscellaneous Field Studies Map MF-905, scale 1:48,000.

Moore, W.J., and McKee, E.H., 1983, Phanerozoic magmatism and mineralization in the Tooele $1^{\circ}$ by $2^{\circ}$ degrees quadrangle, Utah: Geological Society of America Memoir 157, p. $183-190$. 
Morris, H.T., 1964, Geology of the Eureka Quadrangle Utah and Juab Counties, Utah: U.S. Geological Survey Bulletin 1142-K, p. K1-K29, map scale:1:24,000.

Morris, H.T., 1964, Geology of the Tintic Junction Quadrangle, Tooele, Juab, and Utah Counties, Utah: U.S. Geological Survey Bulletin 1142-L, p. L1-L23, map scale:1:24,000.

Morris, H.T., 1975, Geologic map and sections of the Tintic Mountain quadrangle and adjacent part of the McIntyre quadrangle, Juab and Utah Counties, Utah: U.S. Geological Survey Miscellaneous Investigations Series Map I-883, scale 1:24,000.

Morris, S.K., 1980, Geology and ore deposits of Mineral Mountain, Washington County, Utah: Brigham Young Geology Studies v. 27, pt. 2, p. 85-102.

Morris, Hal T., 1987, Preliminary geologic map of the Delta 2 degrees quadrangle, Tooele, Juab, Millard, and Utah counties, Utah: U.S. Geological Survey Open-File Report $87-185$, scale $1: 250,000$

Morris, H.T., and Kopf, R.W., 1967, Breccia pipes in the west Tintic and Sheeprock Mountains, Utah: U.S. Geological Survey Professional Paper 575-C, p. C66-C71.

Morris, H.T., and Lovering, T. S., 1979, General geology and mines of the East Tintic mining district, Utah and Juab counties, Utah: U.S. Geological Survey Professional Paper 1024, 203 p.

Mutschler, F.E., Larson, E. E., Ross, M.L., 1998, Potential for alkaline igneous rock-related gold deposits in the Colorado Plateau laccolithic centers, in, Friedman, J.D., and Huffman, A.C., Jr., Laccolith complexes of southeastern Utah: time of emplacement and tectonic setting-workshop proceedings: U.S. Geological Survey Bulletin 2158, 233-252.

Naeser, C.W., and Stuart-Alexander, D.E., 1969, The age and temperature of the Mule Ear diatreme, southeast Utah [abstract]: Geological Society of America Abstracts with Programs pt. 7, p. 155-156. 
Nelson, S.T., Davidson, J.P., Sullivan, K.R., 1992, New age determinations of central Colorado Plateau laccoliths, Utah: recognizing disturbed K-Ar systematics and re-evaluating tectonomagmatic relationships: Geological Society of America Bulletin, v. 104, p. 1,547-1,560.

Nelson, S.T., and Davidson, J.P., 1998, The petrogenesis of the Colorado Plateau laccoliths and their relationship to regional magmatism, in, Friedman, J.D., and Huffman, A.C., Jr., Laccolith complexes of southeastern Utah: time of emplacement and tectonic setting-workshop proceedings: U.S. Geological Survey Bulletin 2158, p 85-100.

Nielson, D.L., Evans, S.H., Jr., and Sibbett, B.S., 1986, Magmatic, structural, and hydrothermal evolution of the Mineral Mountains intrusive complex, Utah: Geological Society of America Bulletin, v. 97, p. 765-777.

Nolan, T.B., 1935, The geology of the Gold Hill mining district, Utah: U.S. Geological Survey Professional Paper 177, 172 p.

Nutt, C.J., Zimbelman, D.R., Campbell, D.L., Duval, J.S., and Hannigan, B.J., 1990, Mineral resources of the Deep Creek Mountains Wilderness Study Area, Juab and Tooele Counties, Utah: U.S. Geological Survey Bulletin 1745-C, 40 p.

O’Sullivan, R.B., 1965, Geology of the Cedar Mesa-Boundary Butte area, San Juan County, Utah: U.S. Geological Survey Bulletin 1186, 128 p.

Pampeyan, E.H., 1989, Geologic map of the Lynndyl 30- by 60 -minute quadrangle, westcentral Utah: U.S. Geological Survey Map Miscellaneous Investigations Series I-1830, 9 p., scale 1:100,000.

Plavidal, K.R., 1987, The geology (geochemistry) and petrology of the eastern Keg Mountains, Juab County, Utah: Salt Lake City, University of Utah, M.S. thesis, 137 p.

Presnell, R.D., 1997, Structural controls on the plutonism and metallogeny in the Wasatch and Oquirrh Mountains, Utah: Society of Economic Geologists Guidebook 29, p. 1-9.

Robinson, J.P., 1993, Provisional geologic map of the Gold Hill quadrangle, Tooele County, Utah: Utah Geological Survey Map 140, scale 1:24,000, 16 p. 
Rodgers, D.W., 1987, Thermal and structural evolution of the southern Deep Creek Range, west central Utah and east central Nevada: Palo Alto, Calif., Stanford University, unpublished $\mathrm{PhD}$ dissertation, 149p.

Rodgers, D.W.,1989, Geologic map of the Deep Creek Mountains Wilderness Study Areas, Tooele and Juab Counties, Utah: U.S. Geological Survey Miscellaneous Field Studies Map MF-2099, scale 1:50,000.

Rowley, P.D., and Barker, D.S., 1978, Geology of the Iron Springs mining district, Utah: Utah Geological Association Publication 7, p.49-58.

Rowley, P.D., Mehnert, H.H., Naeser, C.W., Snee, L.W., Cunningham, C.G., Steven, T.A., Anderson, J.J., Sable, E.G., and Anderson, R.E., 1994, Isotopic ages and stratigraphy of Cenozoic rocks of the Marysvale volcanic field and adjacent areas, west-central Utah: U.S. Geological Survey Bulletin 2071, 35 p.

Schaeffer, F.E., 1960. Igneous rocks of the central and southern Silver Island Mountains: Guidebook to the geology of Utah, no. 15, p.121-124.

Shubat, M.A., Felger, T.J., and King, J.K., 1999, Geologic map of the Keg Mountain Ranch quadrangle, Juab County, Utah: Utah Geological Survey Miscellaneous Publication 99-5, 22 p, scale 1:24,000.

Sibbett, B.S., and Nielson, D.L., 1980, Geology of the central Mineral Mountains Beaver County, Utah: Utah University Research Institute, Earth Science Laboratory Report DOE/ET/28392-40, 42 p.

Stevens, T.A., and Morris, H.T.,1987, Summary mineral resource appraisal of the Richfield $1^{\circ} \times 2^{\circ}$ quadrangle, west-central Utah: U.S. Geological Survey Circular 916, 24 p.

Stevens, T.A., Morris, H.T., and Rowley, P.D., 1990, Geologic map of the Richfield $1^{\circ} \times 2^{\circ}$ quadrangle, west-central Utah: U.S. Geological Survey Map I-1901, scale 1:250,000.

Stoeser, D.B., 1993, Tertiary calderas and regional extension of the east-central part of the Tintic-Deep Creek mineral belt, eastern Great Basin, Utah: U.S. Geological Survey Bulletin 2039, p. 5-23. 
Stoeser, D.B., Campbell, D.L., Labson, V., Zimbelman, D.R., Podwysocki, M.H., Brickey, D.W., Duval, J.S., Cook, D.L, Lundby, W., 1990, Mineral Resources of the Notch Peak Wilderness Study Area, Millard County, Utah: U.S. Geological Survey Bulletin 1749-C, $1-28$.

Stuart-Alexander, D.E., Shoemaker, E.M., and Moore, H.J., 1972, Geologic map of the Mule Ear diatreme San Juan County, Utah: U.S. Geological Survey Miscellaneous Investigations Series Map I-674, scale 1:2,400.

Sullivan, K.R., Kowallis, B.J., and Mehnert, H.H., 1991, Isotopic ages of igneous intrusions in southeastern Utah--Evidence for a mid-Cenozoic Reno-San Juan magmatic zone: Brigham Young University Geology Studies, v. 37, p. 139-144.

Stacey, J.S., and Zartman, R.E., 1978, A lead and strontium isotopic study of igneous rocks and ores from the Gold Hill mining district, Utah: Utah Geology v. 5, p. 1-15.

Stein, Holly J; Kelley, David L; Kaminsky, Jon F; Gordon, Ian R., 1988, Field trip guide for the West Tintic mining district, western Utah: U.S. Geological Survey Open-File Report 88-0558, $12 \mathrm{pp}$.

Stevens, T.A., and Morris, H.T., 1987, Summary Mineral Resource Appraisal of the Richfield $1 \infty \times 2 \infty$ quadrangle, west-central Utah: U.S. Geological Survey Circular 916, 24 p.

Thompson, K.C., 1973, Mineral deposits of the Deep Creek Mountains, Tooele and Juab Counties, Utah: Utah Geological and Mineralogical Survey Bulletin 99, 76 p.

Tobey, E.F., 1976, Geology of the Bull Valley intrusive-extrusive complex and genesis of the associated iron deposits: University of Oregon, PhD dissertation, 244 p.

Vogel, T.A., Cambray, F.W., Feher, L., and Constenius, K.N., 1997, Petrochemistry and emplacement history of the Wasatch igneous belt, Utah: Society of Economic Geologists Guidebook 29, p. 35-46.

Warnaars, F.W., Smith, W.H., Bray, R.E., Lanier, G., and Shafiqullah, M., 1978, Geochronology of igneous intrusions and porphyry copper mineralization at Bingham, Utah: Economic Geology, v. 73, p. 1,242-1,249. 
Whelan, J.A., 1973, Mineral resources of the Milford area, , in, Hintze L.F. and Whelan, J.A., eds., Geology of the Milford area: Utah Geological Association Publication 3, p. 23-26.

Whelan, J.A., 1982, Geology, ore deposits and mineralogy of the Rocky Range, near Milford, Beaver County, Utah: Utah Geological and Mineral Survey Special Studies 57, 35 p.

Williams, P.E, and Hackman, R.J., 1971, Geology of the Salina quadrangle, Utah: U.S. Geological Survey Map Miscellaneous Investigations Series I-591-A, scale 1:250,000.

Wong, G., 1983, Preliminary map of the resource areas in the Basin and Range Province of Utah: U.S. Geological Survey Open-File Report 83-722, 19 p.

Wray, W.B., Jr., 1973, Geology and mineralization of the Rebel mine area, Star Range, Beaver County, Utah, in, Hintze L.F. and Whelan, J.A., eds., Geology of the Milford area: Utah Geological Association Publication 3, p. 39-41. 


\section{References by location}

\section{SE Utah, including Henry, La Sal, Abajo laccoliths, scattered laccoliths in Salina quadrangle, and diatremes}

Billingsley, G.H., Huntoon, D.W., and Breed, W.J., 1987, Geologic map of the Capital Reef National Park and vicinity, Utah: State of Utah, Department of Natural Resources, Utah Geologic and Mineral Survey Map 87, scale 1:62,500.

Delaney, P.T., and Gratner, A.E., 1997, Physical processes of shallow mafic dike emplacement near the San Rafael Swell, Utah: Geological Society of America Bulletin v. 109 , no. 9, p. 1177-1192.

Gartner, A.E., and Delaney, P.T., 1988, Geologic map showing a late Cenozoic basaltic intrusive complex, Emery, Sevier, and Wayne Counties, Utah: U.S. Geological Survey Map MF-2052, scale 1:48,000.

Hunt, C.B., 1953, Geology and geography of the Henry Mountains region, Utah: U.S. Geological Survey Professional Paper 228, 234 p.

Hunt, G.L., 1988, Petrology of the Mt. Pennell central stock, Henry Mountains, Utah: Bingham Young University Geology Studies, v. 35, p.81-100.

Jackson, M., 1998, Processes of laccolithic emplacement in the southern Henry Mountains, southeastern Utah, in, Friedman, J.D., and Huffman, A.C., Jr., Laccolith complexes of southeastern Utah: time of emplacement and tectonic setting-workshop proceedings: U.S. Geological Survey Bulletin 2158, 51-59.

Mutschler, F.E., Larson, E. E., Ross, M.L., 1998, Potential for alkaline igneous rock-related gold deposits in the Colorado Plateau laccolithic centers, in, Friedman, J.D., and Huffman, A.C., Jr., Laccolith complexes of southeastern Utah: time of emplacement and tectonic setting-workshop proceedings: U.S. Geological Survey Bulletin 2158, 233-252. 
Naeser, C.W., and Stuart-Alexander, D.E., 1969, The age and temperature of the Mule Ear diatreme, southeast Utah [abstract]: Geological Society of America Abstracts with Programs pt. 7, p. 155-156.

Nelson, S.T., Davidson, J.P., Sullivan, K.R., 1992, New age determinations of central Colorado Plateau laccoliths, Utah: recognizing disturbed K-Ar systematics and re-evaluating tectonmagmatic relationships: Geological Society of America Bulletin, v. 104, p. 1,547-1,560.

Nelson, S.T., and Davidson, J.P., 1998, The petrogenesis of the Colorado Plateau laccoliths and their relationship to regional magmatism, in, Friedman, J.D., and Huffman, A.C., Jr., Laccolith complexes of southeastern Utah: time of emplacement and tectonic setting-workshop proceedings: U.S. Geological Survey Bulletin 2158, p 85-100.

O’Sullivan, R.B., 1965, Geology of the Cedar Mesa-Boundary Butte area, San Juan County, Utah: U.S. Geological Survey Bulletin 1186, 128 p.

Stuart-Alexander, D.E., Shoemaker, E.M., and Moore, H.J., 1972, Geologic map of the Mule Ear diatreme San Juan County, Utah: U.S. Geological Survey Miscellaneous Investigations Series Map I-674, scale 1:2,400.

Sullivan, K.R., Kowallis, B.J., and Mehnert, H.H., 1991, Isotopic ages of igneous intrusions in southeastern Utah--Evidence for a mid-Cenozoic Reno-San Juan magmatic zone: Brigham Young University Geology Studies, v. 37, p. 139-144.

Williams, P.E, and Hackman, R.J., 1971, Geology of the Salina quadrangle, Utah: U.S. Geological Survey Map Miscellaneous Investigations Series I-591-A, scale 1:250,000.

\section{Cedar City region, including iron axis}

Armstrong, R.L., 1970, Geochronology of Tertiary igneous rocks, eastern Basin and Range province, western Utah, eastern Nevada, and vicinity, U.S.A. : Geochimica et Cosmochimica Acta, v. 34, p. 203-232.

Barker, D.S., 1995, Crystallization and alteration of quartz monzonite, Iron Springs mining district, Utah: relation to associated iron deposits: Economic Geology, v. 90, p. 2,1972,217 . 
Eppinger, R.G., Winkler, G.R., Cookro, T.M., Shubat, M.A., Blank, H.R., Crowley, J.K., Kucks, R.P. and Jones, J.L., 1990, Preliminary assessment of the mineral resources of the Cedar City $1^{\circ} \times 2^{\circ}$ quadrangle, Utah: U.S. Geological Survey Open-File Report 90-34, $146 \mathrm{p}$.

Hacker, D.B., 1998, Catastrophic gravity sliding and volcanism associated with the growth of laccoliths: examples from early Miocene hypabyssal intrusions of the Iron Axis magmatic province, Pine Valley Mountains, southwest Utah: PhD dissertation, Kent State University, Kent, Ohio, 493 p.

Hintze, L.F., 1986, Stratigraphy and structure of the Beaver Dam Mountains, Southwestern Utah: Utah Geological Association Publication 15, p. 1-36.

McKee, E.H., Blank, H.R., and Rowley, P.D., 1997, Potassium-argon ages of Tertiary igneous rocks in the eastern Bull Valley Mountains and the Pine Valley Mountains, southwestern Utah: U.S. Geological Survey Bulletin 2153-L, p.243-252.

Morris, S.K., 1980, Geology and ore deposits of Mineral Mountain, Washington County, Utah: Brigham Young Geology Studies v. 27, pt. 2, p. 85-102.

Rowley, P.D., and Barker, D.S., 1978, Geology of the Iron Springs mining district, Utah: Utah Geological Association Publication 7, p.49-58.

Tobey, E.F., 1976, Geology of the Bull Valley intrusive-extrusive complex and genesis of the associated iron deposits: University of Oregon, PhD dissertation, 244 p.

\section{Richfield region}

Best, M.G., Lemmon, D.M., and Morris, H.T., 1989, Geologic map of the Milford quadrangle and east half of the Frisco quadrangle, Beaver County, Utah: U.S. Geological Survey Miscellaneous Investigations Series Map I-1904, scale 1:50,000.

Stevens, T.A., and Morris, H.T.,1987, Summary mineral resource appraisal of the Richfield $1^{\circ} \times 2^{\circ}$ quadrangle, west-central Utah: U.S. Geological Survey Circular 916, 24 p.

Stevens, T.A., Morris, H.T., and Rowley, P.D., 1990, Geologic map of the Richfield $1^{\circ} \times 2^{\circ}$ quadrangle, west-central Utah: U.S. Geological Survey Map I-1901, scale 1:250,000. 
Whelan, J.A., 1973, Mineral resources of the Milford area, , in, Hintze L.F. and Whelan, J.A., eds., Geology of the Milford area: Utah Geological Association Publication 3, p. 23-26.

Wong, G., 1983, Preliminary map of the resource areas in the Basin and Range Province of Utah: U.S. Geological Survey Open-File Report 83-722, 19 p.

Whelan, J.A., 1973, Mineral resources of the Milford area, , in, Hintze L.F. and Whelan, J.A., eds., Geology of the Milford area: Utah Geological Association Publication 3, p. 23-26.

Mineral Mountains

Nielson, D.L., Evans, S.H., Jr., and Sibbett, B.S., 1986, Magmatic, structural, and hydrothermal evolution of the Mineral Mountains intrusive complex, Utah: Geological Society of America Bulletin, v. 97, p. 765-777.

Aleinikoff, J.N., Nielson, D.L., Hedge, C.E., and Evans, S.H., Jr., 1986, Geochronology of Precambrian and Tertiary rocks in the Mineral Mountains, south-central Utah: U.S. Geological Survey Bulletin 1622, p. 1-12.

Sibbett, B.S., and Nielson, D.L., 1980, Geology of the central Mineral Mountains Beaver County, Utah: Utah University Research Institute, Earth Science Laboratory Report DOE/ET/28392-40, 42p.

Beaver Mountains

Barosh, P.J., 1960, Beaver Lake Mountains, Beaver County, Utah--their geology and ore deposits: Utah Geological and Mineralogical Survey Bulletin 68, 89 p.

Lemmon, D.M., and Morris, H.T., 1984, Geologic map of the Beaver Lake Mountains quadrangle, Millard and Beaver Counties, Utah: U.S. Geological Survey Miscellaneous Investigations Series Map I-1572, scale 1:48,000.

Lemmon, D.M., Silberman, M.L., and Kistler, R.W., 1973, Some K-Ar ages of extrusive and intrusive rocks of the San Francisco and Wah Wah mountains, Utah, in, Hintze L.F. and Whelan, J.A., eds., Geology of the Milford area: Utah Geological Association Publication 3, p. 23-26. 


\section{Rocky Range region}

Whelan, J.A., 1982, Geology, ore deposits and mineralogy of the Rocky Range, near Milford, Beaver County, Utah: Utah Geological and Mineral Survey Special Studies 57, 35 p.

\section{Wah Wah Range region}

Abott, J.T., Best, M.G., and Morris, H.T., 1983, Geologic map of the Pine Grove-Blawn Mountain area, Beaver County, Utah: U.S. Geological Survey Miscellaneous Investigations Series Map I-1479, scale 1:24,000.

Hintze, L.F., 1974, Preliminary geologic map of the Wah Wah Summit quadrangle, Millard and Beaver Counties, Utah: U.S. Geological Survey Map MF-637, scale 1:48,000.

Hintze, L.F., Lemmon, D.M., and Morris, H.T., 1984, Geologic map of the Frisco Peak quadrangle, Millard and Beaver Counties, Utah: U.S. Geological Survey Map Miscellaneous Investigations Series I-1573, scale 1:48,000.

Keith, J.D., Shanks, W.C., III, Archibald, D.A., and Farrar, E., 1986, Volcanic and intrusive history of the Pine Grove porphyry Molybdenum system, southwestern Utah: Economic Geology v. 81, p. 553-577.

\section{Star Range region}

Baetcke, G.B., 1969, Stratigraphy of the Star Range and reconnaissance study of three selected mines: PhD dissertation, University of Utah, $184 \mathrm{p}$.

Butler, B.S., 1913, Geology and ore deposits of the San Francisco and adjacent districts, Utah: U.S. Geological Survey Professional Paper 80, 212 p.

Abou-Zied, S., 1973, Geology of the Milford Flat quadrangle, Star district, Beaver County, Utah, in, Hintze L.F. and Whelan, J.A., eds., Geology of the Milford area: Utah Geological Association Publication 3, p. 43-48.

Wray, W.B., Jr., 1973, Geology and mineralization of the Rebel mine area, Star Range, Beaver County, Utah, in, Hintze L.F. and Whelan, J.A., eds., Geology of the Milford area: Utah Geological Association Publication 3, p. 39-41. 
Needle Range

Best, M.G., and Grant, S. K., 1987, Stratigraphy of the volcanic Oligocene Needles Range Group in southwestern Utah and eastern Nevada: U.S. Geological Survey Professional Paper 1433-A, 28 p.

Best, M.G., Mehnert, H.H., Keith, J.D., and Naeser, C.W., 1987, Miocene magmatism and tectonism in and near the southern Wah Wah Mountains, southwestern Utah: U.S. Geological Survey Professional Paper 1433-B, 31-47.

Fleck, R.J., Anderson, J.J., and Rowley, P.D., 1975, Chronology of mid-Tertiary volcanism in High Plateaus region of Utah, in Cenozoic geology of southwestern High Plateaus of Utah: Geological Society of America Special Paper 160, p. 53-61.

\section{Gillies Hill region}

Machette, M.N., and Steven, T.A., 1983, Geologic map of the northwest-quarter of the Beaver Quadrangle, Beaver County, Utah: U.S. Geological Survey Map Miscellaneous Investigations Series I-1445, scale 1:24,000.

Machette, M.N., 1983, Geologic map of the southwest-quarter of the Beaver quadrangle, Beaver County, Utah: U.S. Geological Survey Miscellaneous Investigations Series Map I-1444, scale 1:24,000.

Marysvale

Cunningham, C.G., Rasmussen, J.D., Steven, T.A., Rye, R.O., Rowley, P.D., Romberger, S.B., and Selverstone, J., 1998, Hydrothermal uranium deposits containing molybdenum and fluorite in the Marysvale volcanic field, west-central Utah: Mineralium Deposita 33, p. 477-494.

Cunningham, C.G., Steven, T.A., Rowley, P.D., Naeser, C.W., Mehnert, H.H., Hedge, C.E., and Ludwig, K.R., 1994, Evolution of volcanic rocks and associated ore deposits in the Marysvale volcanic field, Utah: Economic Geology, v. 89, p. 2,003-2,005. 
Cunningham, C.G., Steven, T.A., Rowley, P.D., Glassgold, L.B., and Anderson, J.J., 1993, Geologic map of the Tushar Mountains and adjoining areas, Marysvale volcanic field, Utah: U.S. Geological Survey Miscellaneous Investigations Series Map I-1430-A.

Lindgren, W., 1905, The Annie Laurie mine, Piute County, Utah: U.S. Geological Bulletin 285, p.87-90.

Rowley, P.D., Mehnert, H.H., Naeser, C.W., Snee, L.W., Cunningham, C.G., Steven, T.A., Anderson, J.J., Sable, E.G., and Anderson, R.E., 1994, Isotopic ages and stratigraphy of Cenozoic rocks of the Marysvale volcanic field and adjacent areas, west-central Utah: U.S. Geological Survey Bulletin 2071, 35 p.

Stevens, T.A., and Morris, H.T., 1987, Summary Mineral Resource Appraisal of the Richfield $1 \infty \times 2 \infty$ quadrangle, west-central Utah: U.S. Geological Survey Circular 916, 24 p.

\section{Pavant Range region}

George, S.E., 1985, Geology of the Fillmore and Kanosh quadrangles, Millard County, Utah: Brigham Young University Geology Studies v. 32, part 1, p. 39-62.

\section{Delta quadrangle}

Morris, Hal T., 1987, Preliminary geologic map of the Delta 2 degrees quadrangle, Tooele, Juab, Millard, and Utah counties, Utah: U.S. Geological Survey Open-File Report $87-185$, scale $1: 250,000$

Lindsey, D.A., Naeser, C.W., and Shawe, D.R., 1975, Ages of volcanism, intrusion and mineralization in the Thomas Range, Keg Mountain and Desert Mountain, western Utah: U.S. Geological Survey Journal of Research, v. 3, no. 5, p. 597-604.

Pampeyan, E.H., 1989, Geologic map of the Lynndyl 30- by 60 -minute quadrangle, westcentral Utah: U.S. Geological Survey Map Miscellaneous Investigations Series I-1830, 9 p., scale 1:100,000.

\section{Sheeprock region}

Christiansen, E.H., 1995, Granites, subduction, and extension in the basin and range province, western USA: U.S. Geological Survey Circular 1129, p. 35-36. 
Christiansen, E.H., Stuckless, J.S., Funkhouser-Marolf, M.J., and Howell, K.H., 1985, Canadian Institute of Mining and Metallurgy Special Volume 39, p. 303-321.

Keith, J.D., Whitney, J.A., Hattori, K., Ballantyne, G.H., Christiansen, E.H., Barr, D.L., Cannan, T.M., and Hook, C.J., 1997, The role of magmatic sulfides and mafic alkaline magmas in the Bingham and Tintic mining districts, Utah: Journal of Petrology, v. 38, p. $1679-1690$.

Morris, Hal T., 1987, Preliminary geologic map of the Delta 2 degrees quadrangle, Tooele, Juab, Millard, and Utah counties, Utah: U.S. Geological Survey Open-File Report $87-185$, scale $1: 250,000$

Morris, H.T., and Kopf, R.W., 1967, Breccia pipes in the west Tintic and Sheeprock Mountains, Utah: U.S. Geological Survey Professional Paper 575-C, p. C66-C71.

\section{Tintic region}

Hannah, J.L., and Macbeth, A., 1990, Magmatic history of the East Tintic Mountains, Utah: U.S. Geological Survey Open-File Report 90-0095, 24 p.

Hildreth, S.C., Jr., and Hannah, J.L., 1996, Fluid inclusion and sulfur isotope studies of the Tintic mining district, Utah: implications for targeting fluid sources: Economic Geology v. 91 , p. 1,270-1,281.

Keith, J.D., Whitney, J.A., Hattori, K., Ballantyne, G.H., Christiansen, E.H., Barr, D.L., Cannan, T.M., and Hook, C.H., 1997, The role of magmatic sulfides and mafic alkaline magmas in the Bingham and Tintic mining districts, Utah: Journal of Petrology, v. 38, no. 12 , p. 1,679-1,690.

Keith, J.D., Dallmeyer, R.D., Kim, C.S., and Kowallis, B.J., 1991, The volcanic history and magmatic sulfide mineralogy of latites of the central East Tintic Mountains, Utah, in Raines, G.L., Lisle, R.E., Schafer, R.W., and Wilkinson, W.H., eds., Geology and Ore Deposits of the Great Basin: Geological Society of Nevada Symposium Proceedings, Reno/Sparks, Nevada, April 1991, p. 461-483. 
Kim, Choon-Sik, 1997, Petrology of productive intrusions and comagmatic volcanic rocks in the Tintic and East Tintic mining districts, Utah, U.S.A. (1): petrography, mineralogy, and intensive variables: Geoscience Journal, v. 1, no. 3, p. 123-135.

Morris, H.T., 1964, Geology of the Eureka Quadrangle Utah and Juab Counties, Utah: U.S. Geological Survey Bulletin 1142-K, p. K1-K29, map scale:1:24,000.

Morris, H.T., 1964, Geology of the Tintic Junction Quadrangle, Tooele, Juab, and Utah Counties, Utah: U.S. Geological Survey Bulletin 1142-L, p. L1-L23, map scale:1:24,000.

Morris, H.T., 1975, Geologic map and sections of the Tintic Mountain quadrangle and adjacent part of the McIntyre quadrangle, Juab and Utah Counties, Utah: U.S. Geological Survey Miscellaneous Investigations Series Map I-883, scale 1:24,000.

Morris, H.T., and Lovering, T. S., 1979, General geology and mines of the East Tintic mining district, Utah and Juab counties, Utah: U.S. Geological Survey Professional Paper 1024, 203 p.

Stein, Holly J; Kelley, David L; Kaminsky, Jon F; Gordon, Ian R., 1988, Field trip guide for the West Tintic mining district, western Utah: U.S. Geological Survey Open-File Report 88-0558, $12 \mathrm{pp}$.

\section{Keg Mountain region}

Shubat, M.A., Felger, T.J., and King, J.K., 1999, Geologic map of the Keg Mountain Ranch quadrangle, Juab County, Utah: Utah Geological Survey Miscellaneous Publication 99-5, 22 p, scale 1:24,000.

Plavidal, K.R., 1987, The geology (geochemistry) and petrology of the eastern Keg Mountains, Juab County, Utah: Salt Lake City, University of Utah, M.S. thesis, 137 p.

\section{Deep Creek Range region}

Thompson, K.C., 1973, Mineral deposits of the Deep Creek Mountains, Tooele and Juab Counties, Utah: Utah Geological and Mineralogical Survey Bulletin 99, 76 p. 
Nutt, C.J., Zimbelman, D.R., Campbell, D.L., Duval, J.S., and Hannigan, B.J., 1990, Mineral resources of the Deep Creek Mountains Wilderness Study Area, Juab and Tooele Counties, Utah: U.S. Geological Survey Bulletin 1745-C, 40 p.

Rodgers, D.W., 1987, Thermal and structural evolution of the southern Deep Creek Range, west central Utah and east central Nevada: Palo Alto, Calif., Stanford University, unpublished $\mathrm{PhD}$ dissertation, 149p.

Rodgers, D.W.,1989, Geologic map of the Deep Creek Mountains Wilderness Study Areas, Tooele and Juab Counties, Utah: U.S. Geological Survey Miscellaneous Field Studies Map MF-2099, scale 1:50,000.

\section{Kern Mountains region}

Best, M.G., Armstrong, R.I., Graustein, W.C., Embree, G.F., and Ahlborn, R.C., 1974, Mica granites of the Kern Mountains plutons, eastern White Pine Country, Nevada: remobilized basement of the Cordilleran migeosyncline:Geological Society of America Bulletin, v. 85, p. 1,277-1,286.

Miller, E.L., Gans, P.B., Wright, J.E., and Sutter, J.F., 1988, Metamorphic history of the eastcentral basin and range province: tectonic setting and relationship to magmatism, in Ernst, W.G., ed., Metamorphism and crustal evolution of the western United States: Rubey Volume 7, p. 249-282.

\section{Notch Peak region}

Lee, D.E., Stacey, J.S., and Fischer, L.B., 1986, Muscovite-phenocrystic two-mica granites of northeastern Nevada are late Cretaceous in age: U.S. Geological Survey Bulletin 1622, p. 31-39.

Stoeser, D.B., Campbell, D.L., Labson, V., Zimbelman, D.R., Podwysocki, M.H., Brickey, D.W., Duval, J.S., Cook, D.L, Lundby, W., 1990, Mineral Resources of the Notch Peak Wilderness Study Area, Millard County, Utah: U.S. Geological Survey Bulletin 1749-C, $1-28$. 


\section{Desert Mountain region}

Christiansen, E.H., 1995, Granites, subduction, and extension in the Basin and Range province, western USA: U.S. Geological Survey Circular 1129, p.35-36.

Stoeser, D.B., 1993, Tertiary calderas and regional extension of the east-central part of the Tintic-Deep Creek mineral belt, eastern Great Basin, Utah: U.S. Geological Survey Bulletin 2039, p. 5-23.

\section{Salt Lake City 30' x 60' quadrangle}

\section{Little Cottonwood, Alta, Park City and east}

Best, M.G. Henage, L.F., and Adams, J.A.S.., 1968, Mica peridotite, wyomingite, and associated potassic igneous rocks in northeastern Utah: American Mineralogist, v. 53, p. 1041-1048.

Bryant, B., 1990, Geologic map of the Salt Lake City $30^{\prime} \times 60^{\prime}$ quadrangle, north-central Utah, and Unita County, Wyoming: U.S. Miscellaneous Investigations Series Map I-1944, scale 1:100,000.

Baker, A.A., Calkins, F.C., Crittenden, M.D., Jr., and Bromfield, C.S., 1966, Geologic map of the Brighton quadrangle, Utah: U.S. Geological Survey Geologic Quadrangle Map GQ-534, scale 1:24,000.

Borrok, D., Kesler, S. E., Vogel, T. A.: 1999, Sulfide mineral in intrusive and volcanic rocks of the Bingham-Park City Belt, Utah: Economic Geology, v.94, p.1,213-1,230.

Crittenden, M.D., Jr., 1965, Geology of the Draper quadrangle, Utah: U.S. Geological Survey Geologic Quadrangle Map GQ-377, scale 1:24,000.

Crittenden, M.D., Jr., 1965, Geology of the Dromedary Peak quadrangle, Utah: U.S. Geological Survey Geologic Quadrangle Map GQ-378, scale 1:24,000.

Crittenden, M.D., Jr., 1965, Geology of the Mount Aire quadrangle, Salt Lake County, Utah: U.S. Geological Survey Geologic Quadrangle Map GQ-379, scale 1:24,000. 
Crittenden, M.D., Jr., 1965, Geology of the Sugar House quadrangle, Salt Lake County, Utah: U.S. Geological Survey Geologic Quadrangle Map GQ-380, scale 1:24,000.

Crittenden, M.D., Jr., Calkins, F.C., and Sharp, B.J., 1966, Geologic map of the Park City West quadrangle, Utah: U.S. Geological Survey Geologic Quadrangle Map GQ-535, scale $1: 24,000$.

Crittenden, M.S., Jr., Stuckless, J.S., Kistler, R.W., and Stern, T.W., 1973, Radiometric dating of intrusive rocks in the Cottonwood area: U.S. Geological Survey Journal of Research, v. 1, p. 173-178.

John, D.A., 1989, Geologic setting, depths of emplacement, and regional distribution of fluid inclusions in intrusions of the central Wasatch Mountains, Utah: Economic Geology v. 84, p. 386-409.

John, D.A., 1997, Geologic setting and characteristics of mineral deposits in the central Wasatch Mountains, Utah: Society of Economic Geologists Guidebook 29, p. 11-33.

John, D.A., Turrin, B.D., and Miller, R.J., 1997, New K-Ar and ${ }^{40} \mathrm{Ar} /{ }^{39} \mathrm{Ar}$ ages of plutonism, hydrothermal alteration, and mineralization in the central Wasatch Mountains, Utah: : Society of Economic Geologists Guidebook 29, p. 47-57.

Vogel, T.A., Cambray, F.W., Feher, L., and Constenius, K.N., 1997, Petrochemistry and emplacement history of the Wasatch igneous belt, Utah: Society of Economic Geologists Guidebook 29, p. 35-46.

\section{TOOELE quadrangle?}

\section{Oquirrh Mountains}

Babcock, R.C., Jr., Ballantyne, G.H., Phillips, C.H., 1997, Summary of the geology of the Bingham district, Utah: Society of Economic Geologists Guidebook 29, p. 113-132.

Deino, A., and Keith, J.D., 1997, Ages of volcanic and intrusive rocks in the Bingham mining district, Utah: Society of Economic Geologists Guidebook 29, p. 91-100. 
Laes, D.Y.M., Krahulec, K.S., and Ballantyne, G.H., 1997, Geologic map of the Oquirrh Mountains, Utah: Society of Economic Geologists Guidebook 29, Plate 1, scale $1: 62,500$.

Presnell, R.D., 1997, Structural controls on the plutonism and metallogeny in the Wasatch and Oquirrh Mountains, Utah: Society of Economic Geologists Guidebook 29, p. 1-9.

Warnaars, F.W., Smith, W.H., Bray, R.E., Lanier, G., and Shafiqullah, M., 1978, Geochronology of igneous intrusions and porphyry copper mineralization at Bingham, Utah: Economic Geology, v. 73, p. 1,242-1,249.

\section{Granite Peak region}

Fowkes, E.J., 1964, Pegmatites of Granite Peak Mountain, Tooele County, Utah: Brigham Young University Research Studies, Geology Series, v.11, p.97-127.

Moore, W J., and Sorensen and, M L., 1978, Metamorphic rocks of the Granite Peak area, Tooele County, Utah [abstract]: Geological Society of America Program with Abstracts, v.10, no.5, p. 234.

\section{Little Granite Peak region}

Moore, W J., and Sorensen and, M L., 1978, Reconnaissance geologic map of northern Simpson Mountains, Davis Mountain, and adjacent area, Tooele County, Utah: U.S. Geological Survey Miscellaneous Field Studies Map MF-905, scale 1:48,000.

\section{Gold Hill region}

Moore, W.J., and McKee, E.H., 1983, Phanerozoic magmatism and mineralization in the Tooele $1^{\circ}$ by $2^{\circ}$ degrees quadrangle, Utah: Geological Society of America Memoir 157, p. 183-190.

Nolan, T.B., 1935, The geology of the Gold Hill mining district, Utah: U.S. Geological Survey Professional Paper 177, 172 p.

Robinson, J.P., 1993, Provisional geologic map of the Gold Hill quadrangle, Tooele County, Utah: Utah Geological Survey Map 140, scale 1:24,000, 16 p. 
Stacey, J.S., and Zartman, R.E., 1978, A lead and strontium isotopic study of igneous rocks and ores from the Gold Hill mining district, Utah: Utah Geology v. 5, p. 1-15.

\section{BRIGHAM CITY quadrangle}

Miller, D.M., Nakata, J.K., and Glick, L.L., 1990, K-Ar ages of Jurassic to Tertiary plutonic and metamorphic rocks, northwestern Utah and northeastern Nevada: U.S. Geological Survey Bulletin 1906, 18 p.

Miller, D.M. and Hoisch, T.D., 1995, Jurassic tectonics of northeastern Nevada and Northwestern Utah from the perspective of barometric studies: Geological Society of America Special Paper 299, p. 267-294.

\section{Crater Island region}

Miller, D.M., Jordan, T.E., and Allmendinger, R.W., 1990, Geologic map of the Crater Island quadrangle, Box Elder County, Utah: Utah Geological and Mineral Survey Map 128, 16 p, scale $1: 24,000$.

\section{Pilot Mountains}

Miller, D.M., 1985, Geologic map of the Lucin quadrangle, Box Elder County, Utah: Utah Geological Survey Map 78, 10 p, scale 1:24,000.

Miller, D.M., 1993, Geologic map of the Crater Island NW quadrangle, Box Elder County, Utah: Utah Geological Survey Map 145, 13 p, scale 1:24,000.

Miller, D.M., and Schneyer, J.D., 1985, Tecoma Quadrangle, Box Elder County, Utah and Elko County, Nevada: Utah Geological Survey Map 77, 8 p, scale 1:24,000.

\section{Newfoundland Mountains region}

Allmendinger, R.W., and Jordan, T.E., 1989, Geologic map of the Newfoundland Mountains, northwestern Utah: U.S. Geological Survey Map MF-2087, scale 1:31,680. 


\section{Silver Island region}

Schaeffer, F.E., 1960. Igneous rocks of the central and southern Silver Island Mountains: Guidebook to the geology of Utah, no. 15, p.121-124.

\section{Raft River and Grouse Creek Mountains region}

Compton, R.R., 1972, Geologic map of the Yost quadrangle, Box Elder County, Utah and Cassia County, Idaho: U.S. Geological Survey Miscellaneous Investigations Series Map I-672, 7 p., scale 1:31,680.

Compton, R.R., 1972, Geologic map of the Park Valley quadrangle, Box Elder County, Utah and Cassia County, Idaho: U.S. Geological Survey Miscellaneous Investigations Series Map I-873, 6 p., scale 1:31.680.

Compton, R.R., Todd, V.R, Zartman, R.E., and Naser, C.W., 1977, Oligocene and Miocene metamorphism, folding, and low-angle faulting in northwestern Utah: Geological Society of America Bulletin, v. 88, p. 1237-1250.

Doelling, H.H., 1980, Geology and mineral resources of Box Elder County, Utah: Utah Geological and Mineral Survey Bulletin 115, 251 p. 